\title{
Synthesis of Literature Relating to Cellular Telephone/Personal Digital Assistant Use in Commercial Truck and Bus Operations
}

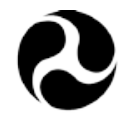

U.S. Department of Transportation

Federal Motor Carrier Safety Administration 


\section{FOREWORD}

The purpose of this project was to investigate the core question of what effects on commercial truck and bus operations arise from driver distraction due to the use of mobile communication devices such as cellular telephones (cell phones) or personal digital assistants (PDAs). Driver distraction is recognized as a causal and contributing factor in collisions involving commercial motor vehicles (CMVs). As part of its overall effort to reduce CMV crashes, the Federal Motor Carrier Safety Administration (FMCSA) seeks to increase the understanding of driver distraction in commercial vehicle operations (CVOs). The work performed under the project involved a review of published driver distraction studies, with a focus on distractions in CVOs.

\section{NOTICE}

This document is disseminated under the sponsorship of the U.S. Department of Transportation in the interest of information exchange. The United States Government assumes no liability for its contents or the use thereof.

The contents of this Report reflect the views of the contractor, who is responsible for the accuracy of the data presented herein. The contents do not necessarily reflect the official policy of the U.S. Department of Transportation.

This Report does not constitute a standard, specification, or regulation.

The United States Government does not endorse products or manufacturers named herein. Trade or manufacturers' names appear herein only because they are considered essential to the objective of this document. 
Technical Report Documentation Page

\begin{tabular}{|c|c|c|c|c|}
\hline $\begin{array}{l}\text { 1. Report No. } \\
\text { FMCSA-RRR-11-015 }\end{array}$ & 2. Government Accession No. & \multicolumn{3}{|c|}{ 3. Recipient's Catalog No. } \\
\hline \multirow{2}{*}{\multicolumn{2}{|c|}{$\begin{array}{l}\text { 4. Title and Subtitle } \\
\text { SYNTHESIS OF LITERATURE RELATING TO CELLULAR } \\
\text { TELEPHONE/PERSONAL DIGITAL ASSISTANT USE IN } \\
\text { COMMERCIAL TRUCK AND BUS OPERATIONS }\end{array}$}} & \multicolumn{3}{|c|}{$\begin{array}{l}\text { 5. Report Date } \\
\text { April } 2011\end{array}$} \\
\hline & & \multicolumn{3}{|c|}{ 6. Performing Organization Code } \\
\hline \multicolumn{3}{|c|}{$\begin{array}{l}\text { 7. Author(s) } \\
\text { Justin F. Morgan, Tammy E. Trimble, Darrell S. Bowman, Stephanie } \\
\text { Baker, Racquel Pickett, Dan Murray, \& Gene Bergoffen }\end{array}$} & \multicolumn{2}{|c|}{ 8. Performing Organization Report No } \\
\hline \multirow{2}{*}{\multicolumn{2}{|c|}{$\begin{array}{l}\text { 9. Performing Organization Name and Address } \\
\text { MaineWay Services } \\
\text { PO Box } 166 \\
\text { Fryeburg, ME } 04037\end{array}$}} & \multicolumn{3}{|c|}{ 10. Work Unit No. (TRAIS) } \\
\hline & & \multicolumn{3}{|c|}{$\begin{array}{l}\text { 11. Contract or Grant No. } \\
\text { BPA DTMC 75-08-A-00001 }\end{array}$} \\
\hline \multirow{2}{*}{\multicolumn{2}{|c|}{$\begin{array}{l}\text { 12. Sponsoring Agency Name and Address } \\
\text { U.S. Department of Transportation } \\
\text { Federal Motor Carrier Safety Administration } \\
1200 \text { New Jersey Ave SE } \\
\text { Washington, DC } 20590\end{array}$}} & \multicolumn{3}{|c|}{$\begin{array}{l}\text { 13. Type of Report } \\
\text { Final Report }\end{array}$} \\
\hline & & \multicolumn{3}{|c|}{ 14. Sponsoring Agency Code } \\
\hline \multicolumn{5}{|l|}{$\begin{array}{l}\text { 15. Supplementary Notes } \\
\text { The Contracting Offic } \\
\text { J.F. Morgan, T.E. Trir } \\
\text { Pickett and D. Murray } \\
\text { Services. }\end{array}$} \\
\hline \multicolumn{5}{|c|}{$\begin{array}{l}\text { There is an increasing awareness of the role of driver distraction in commercial motor vehicle crashes. This study } \\
\text { presents the results of efforts to expand current knowledge of truck and motorcoach industry practices regarding } \\
\text { commercial driver distraction. The project involved a thorough literature review on driver distraction. Little } \\
\text { research specifically addressed commercial driver distraction; those studies that did examine commercial driving } \\
\text { typically found significant degradations in driver performance due to visually demanding device use. However, the } \\
\text { findings of automotive driver distraction research vary based on the type of examination (i.e., simulator, test-track, } \\
\text { or naturalistic data collection methods) and the aspect of phone use. These findings, in light of the importance and } \\
\text { potential safety risks posed by driver distraction, may help guide further research into the nature and magnitude of } \\
\text { distraction faced by CMV drivers as part of their normal job functions. }\end{array}$} \\
\hline \multicolumn{3}{|c|}{$\begin{array}{l}\text { 17. Key Words } \\
\text { cell phone, CMV, commercial motor vehicle, crash avoidance, distraction, } \\
\text { driver distraction, heavy vehicle, motorcoach, PDA, personal digital assistant, } \\
\text { smart phone, survey, truck }\end{array}$} & \multicolumn{2}{|c|}{$\begin{array}{l}\text { 18. Distribution Statement } \\
\text { No restrictions }\end{array}$} \\
\hline $\begin{array}{l}\text { 19. Security Classif. (of this report) } \\
\text { Unclassified }\end{array}$ & $\begin{array}{l}\text { 20. Security Classif. (of this } p \\
\text { Unclassified }\end{array}$ & & $\begin{array}{l}\text { 21. No. of Pages } \\
32\end{array}$ & 22. Price \\
\hline
\end{tabular}

Form DOT F 1700.7 (8-72)

Reproduction of completed page authorized. 


\section{MODERN METRIC) CONVERSION FACTORS}

\section{Table of APPROXIMATE CONVERSIONS TO SI UNITS}

\begin{tabular}{|c|c|c|c|c|}
\hline Symbol & When You Know & Multiply By & To Find & Symbol \\
\hline \multicolumn{5}{|c|}{ LENGTH } \\
\hline in & inches & 25.4 & millimeters & $\mathrm{mm}$ \\
\hline $\mathrm{ft}$ & feet & 0.305 & meters & $\mathrm{m}$ \\
\hline yd & yards & 0.914 & meters & $\mathrm{m}$ \\
\hline $\mathrm{mi}$ & miles & 1.61 & kilometers & $\mathrm{km}$ \\
\hline \multicolumn{5}{|c|}{ AREA } \\
\hline$i n^{2}$ & square inches & 645.2 & square millimeters & $\mathrm{mm}^{2}$ \\
\hline $\mathrm{ft}^{2}$ & square feet & 0.093 & square meters & $\mathrm{m}^{2}$ \\
\hline $\mathrm{yd}^{2}$ & square yards & 0.836 & square meters & $\mathrm{m}^{2}$ \\
\hline ac & acres & 0.405 & hectares & ha \\
\hline $\mathrm{mi}^{2}$ & square miles & 2.59 & square kilometers & $\mathrm{km}^{2}$ \\
\hline & & VOLUME & $\begin{array}{l}\text { Note: Volumes greater than } \\
1000 \mathrm{~L} \text { shall be shown in } \mathrm{m}^{3}\end{array}$ & \\
\hline $\mathrm{fl} \mathrm{oz}$ & fluid ounces & 29.57 & milliliters & $\mathrm{mL}$ \\
\hline gal & gallons & 3.785 & liters & $\mathrm{L}$ \\
\hline $\mathrm{ft}^{3}$ & cubic feet & 0.028 & cubic meters & $\mathrm{m}^{3}$ \\
\hline $\mathrm{yd}^{3}$ & cubic yards & 0.765 & cubic meters & $\mathrm{m}^{3}$ \\
\hline \multicolumn{5}{|c|}{ MASS } \\
\hline $\mathrm{OZ}$ & ounces & 28.35 & grams & $g$ \\
\hline $\mathrm{Ib}$ & pounds & 0.454 & kilograms & $\mathrm{kg}$ \\
\hline $\mathrm{T}$ & short tons (2000 lb) & 0.907 & megagrams (or "metric ton") & Mg (or "t") \\
\hline${ }^{\circ} \mathrm{F}$ & Fahrenheit & $\begin{array}{c}\text { TEMPERATURE } \\
5 \times(\mathrm{F}-32) \div 9 \\
\text { or }(\mathrm{F}-32) \div 1.8\end{array}$ & $\begin{array}{l}\text { Temperature is in exact degrees } \\
\text { Celsius }\end{array}$ & ${ }^{\circ} \mathrm{C}$ \\
\hline \multicolumn{5}{|c|}{ ILLUMMINATION } \\
\hline fc & foot-candles & 10.76 & lux & Ix \\
\hline $\mathrm{fl}$ & foot-Lamberts & 3.426 & candela/m² & $\mathrm{cd} / \mathrm{m}^{2}$ \\
\hline \multicolumn{5}{|c|}{ Force and Pressure or Stress } \\
\hline lbf & poundforce & 4.45 & newtons & $\mathrm{N}$ \\
\hline Ibf/in ${ }^{2}$ & poundforce per square inch & 6.89 & kilopascals & $\mathrm{kPa}$ \\
\hline \multicolumn{5}{|c|}{ Table of APPROXIMATE CONVERSIONS FROM SI UNITS } \\
\hline Symbol & When You Know & Multiply By & To Find & Symbol \\
\hline \multicolumn{5}{|c|}{ LENGTH } \\
\hline $\mathrm{mm}$ & millimeters & 0.039 & inches & in \\
\hline $\mathrm{m}$ & meters & 3.28 & feet & $\mathrm{ft}$ \\
\hline $\mathrm{m}$ & meters & 1.09 & yards & yd \\
\hline $\mathrm{km}$ & kilometers & 0.621 & miles & mi \\
\hline \multicolumn{5}{|c|}{ AREA } \\
\hline $\mathrm{mm}^{2}$ & square millimeters & 0.0016 & square inches & in $^{2}$ \\
\hline $\mathrm{m}^{2}$ & square meters & 10.764 & square feet & $\mathrm{ft}^{2}$ \\
\hline $\mathrm{m}^{2}$ & square meters & 1.195 & square yards & $\mathrm{yd}^{2}$ \\
\hline ha & hectares & 2.47 & acres & ac \\
\hline $\mathrm{km}^{2}$ & square kilometers & 0.386 & square miles & $\mathrm{mi}^{2}$ \\
\hline \multicolumn{5}{|c|}{ VOLUME } \\
\hline $\mathrm{mL}$ & milliliters & 0.034 & fluid ounces & fl oz \\
\hline $\mathrm{L}$ & liters & 0.264 & gallons & gal \\
\hline $\mathrm{m}^{3}$ & cubic meters & 35.314 & cubic feet & $\mathrm{ft}^{3}$ \\
\hline $\mathrm{m}^{3}$ & cubic meters & 1.307 & cubic yards & $\mathrm{yd}^{3}$ \\
\hline \multicolumn{5}{|c|}{ MASS } \\
\hline g & grams & 0.035 & ounces & $\mathrm{OZ}$ \\
\hline $\mathrm{kg}$ & kilograms & 2.202 & pounds & $\mathrm{lb}$ \\
\hline Mg (or "t") & megagrams (or "metric ton") & 1.103 & short tons (2000 lb) & $\mathrm{T}$ \\
\hline${ }^{\circ} \mathrm{C}$ & Celsius & $\begin{array}{c}\text { TEMPERATURE } \\
1.8 \mathrm{C}+32\end{array}$ & $\begin{array}{l}\text { Temperature is in exact degrees } \\
\text { Fahrenheit }\end{array}$ & ${ }^{\circ} \mathrm{F}$ \\
\hline \multicolumn{5}{|c|}{ ILLUMINATION } \\
\hline Ix & $\operatorname{lux}$ & 0.0929 & foot-candles & fc \\
\hline $\mathrm{cd} / \mathrm{m}^{2}$ & candela/m² & 0.2919 & foot-Lamberts & $\mathrm{fl}$ \\
\hline \multicolumn{5}{|c|}{ Force \& Pressure or Stress } \\
\hline $\mathrm{N}$ & newtons & 0.225 & poundforce & lbf \\
\hline $\mathrm{kPa}$ & kilopascals & 0.145 & poundforce per square inch & lbf/in² \\
\hline
\end{tabular}

* SI is the symbol for the International System of Units. Appropriate rounding should be made to comply with Section 4 of ASTM E380. (Revised March 2003, Section 508-accessible version September 2009) 


\section{TABLE OF CONTENTS}

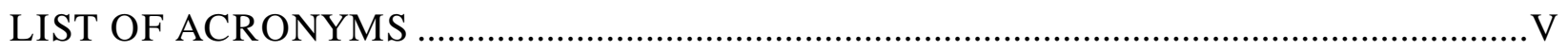

EXECUTIVE SUMMARY ………………………….........................................................

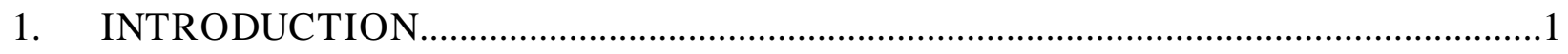

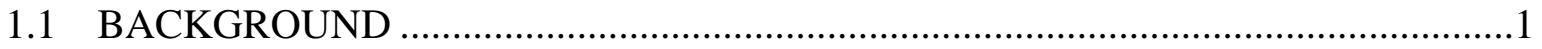

2. DRIVER DISTRACTION LITERATURE SYNTHESIS.............................................

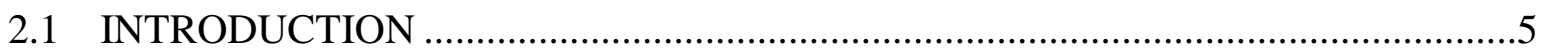

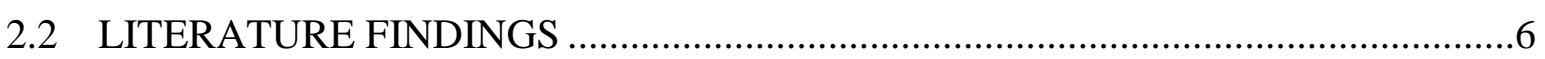

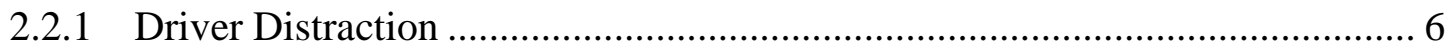

2.2.2 Effects on Driver Performance .................................................................... 8

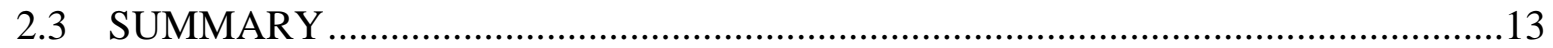

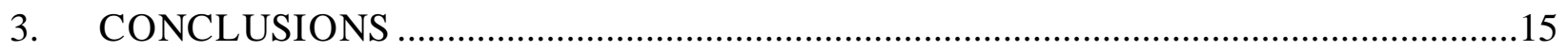

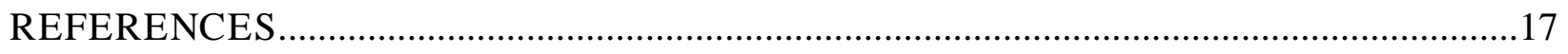

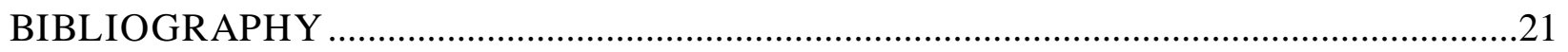




\section{LIST OF FIGURES}

Figure 1. Diagram. States with school bus driver cell phone bans ..........................................2 


\section{LIST OF ACRONYMS}

$\begin{array}{ll}\text { BISC } & \text { Bus Industry Safety Council } \\ \text { CB } & \text { Citizens Band (radio) } \\ \text { CMV } & \text { commercial driver's license } \\ \text { CVO } & \text { commercial motor vehicle } \\ \text { FMCSA } & \text { Federal Motor Carrier Safety Administration } \\ \text { GPS } & \text { Global Positioning System } \\ \text { NHTSA } & \text { National Highway Traffic Safety Administration } \\ \text { PDA } & \text { personal digital assistant } \\ \text { USDOT } & \text { U.S. Department of Transportation }\end{array}$


[This page intentionally left blank.] 


\section{EXECUTIVE SUMMARY}

\section{PURPOSE, RATIONALE, AND BACKGROUND}

The objective of this project is to synthesize findings from the body of published literature relating to cellular telephone (cell phone) use in automobiles, as well as any research findings and conclusions relating to commercial vehicle operations. The question of driver distraction effects in commercial trucking and motorcoach operations is critical due to an increase of both the presence of potentially distracting devices in commercial motor vehicles (CMVs) and our understanding of their potential safety risks. Thus, as a part of its mission to reduce the occurrence of CMV crashes and increase operational safety, the Federal Motor Carrier Safety Administration (FMCSA) seeks to increase the understanding of driver distraction caused by electronic communication devices in commercial vehicle operations (CVOs).

\section{STUDY FINDINGS}

The present study results indicate several key findings. The literature review indicates a relative lack of published research specifically examining driver distraction in commercial vehicle operations. What research is available indicates that the use of visually distracting devices in the cab significantly degrades driver performance. This degradation in driver performance leads to increased risk of critical events (such as pedestrian incursions and traffic signals) being missed by drivers, and increased overall risk of a crash or near-crash. Actions such as entering information into a device or dialing a cell phone require significantly focused attention that leads to increased crash risk. Some evidence suggests that the risk associated with mobile communication devices may be reduced through designs that consider driver workload. However, additional research is needed prior to determining the differential risk from various devices. Furthermore, the results of the literature synthesis also indicate that much of the literature covering commercial driving only examines the effects of distraction on the truck driver; little published literature is specifically related to the bus driver.

It is clear that wireless communication devices, such as cell phones, are widely adopted and present in CMVs. The analysis suggests that these sources of distraction may increase the risk of safety-critical events occurring.

\section{CONCLUSIONS}

These findings, in light of the importance and potential safety risks posed by driver distraction, may help guide further research into the nature and magnitude of distraction faced by CMV drivers as part of their normal job functions. While further research is clearly needed to address these topics of concern, the information obtained in this study will assist policy makers and other stakeholders (i.e., fleet administrators, trainers, and safety professionals) as issues of driver distraction continue to be examined. 
[This page intentionally left blank.] 


\section{INTRODUCTION}

\section{$1.1 \quad$ BACKGROUND}

Due to the increasing presence of wireless technology in vehicles, there has been a growing interest in the effect of wireless communication devices, such as cell phones, on safe driving. This report describes an effort to collect and review the findings of the existing body of literature regarding driver distraction resulting from the use of cell phones and other hand-held electronic devices. Mobile devices such as cellular telephones (cell phones), personal digital assistants (PDAs), and newer smart phones (i.e., phones with advanced Internet, email, and digital media capabilities) have found widespread adoption in the United States. The use of other visually demanding devices, such as portable navigation systems, has greatly increased as well. However, cell phones (including smart phones) have an especially high adoption rate. Industry estimates place the number of wireless subscribers in the United States at more than 270 million, a substantial majority of the nation's population (CTIA-The Wireless Association, 2009). A significant portion of drivers own and use mobile devices, and indications are that many drivers use these devices while driving (AAA Foundation for Traffic Safety, 2008).

Although estimates vary, some studies of specific areas in the U.S. have indicated that approximately 78 percent of crashes are said to involve driver distraction (Klauer, Dingus, Neale, Sudweeks, \& Ramsey, 2006). These crashes have a considerable monetary impact on society, with the annual cost of cell phone-related crashes estimated at \$43 billion for the United States alone (Regan, Lee, \& Young, 2009). In response, many States have enacted some form of cell phone use restriction for all drivers or for a discrete segment of the driving population (e.g., teen drivers, school bus drivers). Hand-held cell phone use while driving is banned in California, Connecticut, Delaware, Maryland, New Jersey, New York, Oregon, Utah, and Washington, as well as in the District of Columbia. Six States (Illinois, Massachusetts, Michigan, New Mexico, Ohio, and Pennsylvania) allow localities to ban cell phone use while driving (Insurance Institute for Highway Safety, 2009). Use of cell phones by school bus drivers while driving is banned (as of August 2010) in 19 States and the District of Columbia. However, these restrictions have not specifically targeted drivers of other bus types (i.e., transit and motorcoach). This State-by-State method has created a patchwork of bans (Figure 1); this situation can prove frustrating to both trucking companies and passenger carriers alike, as well as their drivers. National attention to the perils of driving while texting has prompted several Federal bans on texting while driving:

- In late 2009, President Obama signed an Executive Order prohibiting Federal employees from texting while driving Government-owned vehicles (Executive Order 13,513, 2009).

- In January 2010, the Federal Motor Carrier Safety Administration (FMCSA) issued guidance that bans commercial motor vehicle (CMV) drivers from texting while driving (USDOT, 2010). 


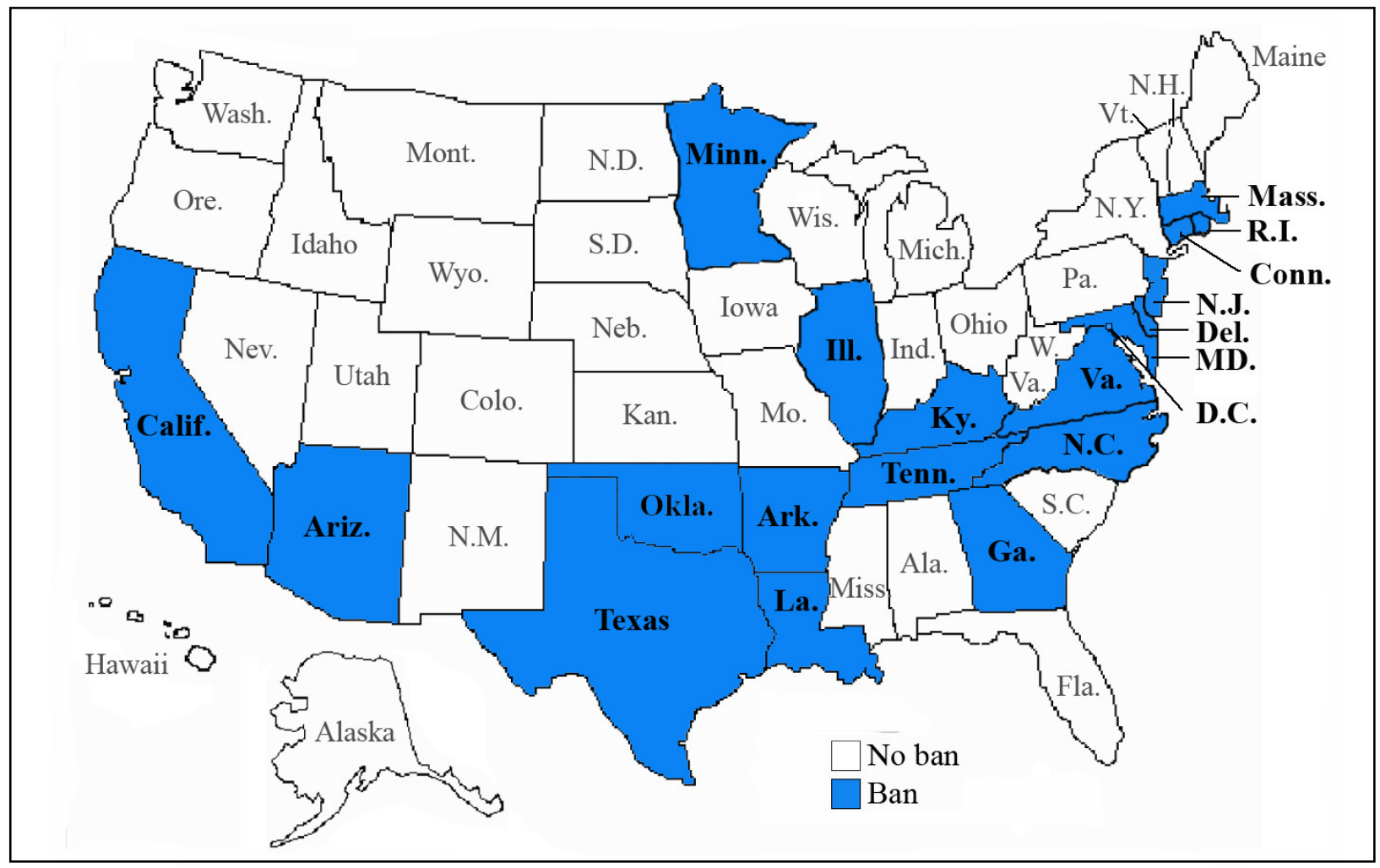

Adapted from Insurance Institute for Highway Safety (2009).

Figure 1. Diagram. States with school bus driver cell phone bans

There is growing international concern about distraction with both CMV operators and automobile drivers. Australian law bans the use of hand-held phones and activities such as texting (Pennay, 2008). Only hands-free modes (such as speakerphones and wireless headsets) are allowed while the vehicle is moving. This legislation is widely supported by the Australian public. Ninety percent of drivers in one survey supported the hand-held phone ban (Pennay). Many provinces in Canada ban hand-held cell phone use, including Newfoundland, Labrador, Nova Scotia, and Quebec. However, the Canada Safety Council reports that no demonstrable safety improvements have been observed from these bans and notes that enforcement of these bans in other countries has not been tracked (Safety Canada, 2004). Similarly, most constituent states of the European Union ban the use of hand-held cell phones during driving (Lissy, Cohen, Park, \& Graham, 2000). Although primarily targeted at automobile drivers, these bans also apply to European CMV drivers.

Restrictions on cell phone use while driving is not a straightforward matter. Despite the known risks associated with using cell phones while driving, the exact magnitude of these risks is uncertain (Lissy, Cohen, Park, \& Graham, 2000). Furthermore, Lissy et al. note that common suggestions such as instructing drivers to pull off the road while operating a cell phone are both unrealistic and potentially more dangerous than using the phone while driving. Goodman et al. (1997) argued that until the true effects of in-vehicle communications are known, attempts to make these systems as compatible as possible with safe driving, rather than restricting access to such technologies, should be the goal. This accords with Hahn and Dudley (2002), who discussed the difficulties in regulating the use of cell phones during driving and concluded that 
the best tactic may be a broader approach, including the regulations of all forms of distraction (e.g., navigation systems and entertainment systems in the vehicle) instead of attempting to target certain rapidly evolving technologies such as cell phones and smart phones.

Interestingly, there appears to be public support for restricting the use of cell phones while driving, even though many drivers do not associate their own use of cell phones while driving with increased risk of a collision. In a 2003 study, Royal surveyed more than 4,000 U.S. drivers and found that, of the 26 percent of those who had had a crash in the past 5 years, only 0.1 percent attributed the crash to cell phone distraction. The AAA Foundation for Traffic Safety (2008) conducted a nationally representative telephone survey of 2,509 U.S. adults aged 18 and older. The survey results indicated that more than 50 percent reported using a cell phone while driving in the past 30 days, and one in seven sent text messages while driving. Also, text messaging and talking on cell phones varied depending on age and education. Younger individuals and those with higher levels of education indicated higher levels of cell phone use and text messaging while driving. Of those surveyed, 83 percent (more than 4 out of 5 drivers) believed that cell phone use while driving posed a serious safety problem, and more than 50 percent indicated that it was unacceptable to use a cell phone while driving. Even though they were slightly less likely to use their cell phones while driving, between 29 and 46 percent of drivers expressing these opinions reported using their phones while driving. Additionally, the survey found that two-thirds of cell phone using drivers believed that it was safer to talk on a hands-free cell phone than a hand-held cell phone. 
[This page intentionally left blank.] 


\section{DRIVER DISTRACTION LITERATURE SYNTHESIS}

\subsection{INTRODUCTION}

Although driver distraction has long been recognized as a threat to safe driving, the majority of driver distraction research has focused on general (automotive) driving. While some studies have addressed driver distraction in commercial heavy truck transportation (Olson, Hanowski, Hickman, \& Bocanegra, 2009), motorcoach operations have not been examined in a similar manner. In order to determine the possible scope and implications of driver distraction on both types of CMV operations (i.e., heavy truck and motorcoach), a wide-ranging literature review was performed. However, it should be noted that both automotive and CMV driver distraction research is a rapidly evolving field. The focus of this literature survey examined research published prior to May 2009, though some key studies published between the completion of the initial literature synthesis and the authoring of this report are also included. More recently published findings, and especially those from real-world data collection efforts, have provided more information on this critical topic of driver distraction.

Additionally, there appear to be major differences in the outcome of driver distraction studies based on the research apparatus. While simulator, and to some extent test-track, studies allow for experimental control over and measurement of the cognitive distractions (such as the type of phone conversation), they have not typically agreed with naturalistic studies' determination of actual risk from phone use while driving. Laboratory and test-track studies may have unrealistic driving and cell phone use conditions, lack of ecologically valid driver choices due to test track or simulated environment restrictions, and lack the risk associated with real world driving (Tijerina, 2010). Another possible explanation for these differences is that the frequency and occurrence of secondary behaviors (including cell phone use) is not consistent in the real world (Sayer, Devonshire, \& Flannagan, 2007), whereas they are often presented in such a manner in simulator and test track experiments. Overall, it is important to keep these differences in mind while comparing the results from different research methods.

Drawing definite conclusions from more limited studies can be problematic. This is because the majority of the extant literature does not separately examine the different sub-tasks associated with cell phone use. For example, the use of a cell phone may involve a variety of sub-tasks, including reaching for and holding the phone, performing the visually complex process of manually dialing the phone, and holding the phone to the ear in order to carry out the conversation. While more recent research (Olson, Hanowski, Hickman, \& Bocanegra, 2009) has identified that these sub-tasks are not equal in risk, most of the prior published body of literature has collapsed measurement across all sub-tasks. The Olson et al. study was able to examine the components of dialing a cell phone (associated with a significant increase in risk) versus talking or listening to the cell phone (not associated with a significant increase in risk). Thus, the risk associated with cell phone use determined from studies that view all facets of cell phone use as the same should not be used to make definite attributions of risk and instead may be viewed as illustrative of general and potential effects of distraction.

Although attempts to mitigate the impact of driver distractions (e.g., staged presentation of distraction-likely messages in heavy-demand driving situations; Verway, 1993) have been 
undertaken, the technology to accomplish this has not been adequately developed. Additionally, while standards (such as the "15-Second Rule") have been proposed to define a maximum allowable in-vehicle device interaction time for visual and manual tasks (SAE International, 2004; Green, 1999), these have not been shown to be sensitive to distraction (Tijerina, Parmer, \& Goodman, 2000). The lack of clear guidance on distraction-likely technologies, coupled with distraction's known impact on automotive driving performance, leads to the obvious need for further empirical research of CMV operator distraction.

The purpose of this report is to synthesize current literature regarding the effect of cell phone/smart phone (including PDA) use on other modes of transportation (i.e., light and heavy vehicles) and discuss implications for the safe operation of trucks and motorcoaches. The research teams gathered existing literature from academic, government, and industry sources. The empirical research findings within these reports and articles have been collected and are summarized herein.

\subsection{LITERATURE FINDINGS}

\subsubsection{Driver Distraction}

Research performed by Treat, Tumbae, McDonald, Shinar, Hume, Mayer, et al. (1977) identified inattention and internal distraction as major contributors to traffic collisions. Epidemiological studies have placed the risk of a collision while using a cell phone as roughly four times that of driving without using a cell phone (Redelmeier \& Tibshirani, 1997). These findings have been given further support from naturalistic observation data that indicate any behaviors requiring eyes-off-road time of greater than 2 seconds increases the risk of a crash or near-crash by more than twice that of nominal driving (Klauer, Dingus, Neale, Sudweeks, \& Ramsey, 2006).

Similar results have been found in naturalistic observation studies of CMV drivers. A study conducted by Hanowski, Perez, and Dingus (2005) determined that driver distraction accounted for 6.5 percent of all safety-critical events recorded during an observation period. Interestingly, Hanowski et al. indicate that 6 percent of the drivers in that study were responsible for approximately one-quarter of the safety-critical events. Safety-critical events are crashes, nearcrashes, crash-relevant conflicts, and unintentional lane deviations. Crashes involve contact with an object. Near-crashes are events that require a rapid evasive maneuver by one of the parties involved. Crash-relevant conflicts are similar to near-crashes, though the severity of the evasive maneuver is less than that in a near-crash. Unintentional lane deviations involve drifting outside of the driving lane. In addition, naturalistic observation studies have suggested a possible link between fatigued and distracted driving in CMV drivers (Barr, Yang, Hanowski, \& Olson, 2005). Of the safety-critical events identified in the data, 60 percent had some type of tertiary task (e.g., non-driving related tasks such as eating) listed as a potential contributing factor (Olson, Hanowski, Hickman, \& Bocanegra, 2009). The most risky distraction found was text messaging; CMV drivers who are text messaging are approximately 23 times more likely to be involved in a safety-critical event compared to non-text-messaging CMV drivers. Further results indicate a significant increase in safety-critical event risk from the use of a cell phone (dialing a cell phone leads to a six times greater risk of a safety-critical event). These naturalistic driving studies have found evidence for a possible relationship between boredom and monotony in the driving task and sensation-seeking through distracting tasks. In addition, as noted by Hancock and Scallen 
(1999), while use of these devices often leads to significantly degraded driver performance, the increase in risk is not always reflected in an increased number of collisions. Instead, these devices increase the overall risk associated with driving and should be viewed as having an interactive effect (due to other roadway environment risk factors) on the actual occurrence of collisions.

This is a critical topic, as a 2007 observational study estimated that, at any given moment during the day, almost 800,000 individuals are simultaneously operating a vehicle and talking on a hand-held cell phone (Glassbrenner and Ye, 2007). This creates a situation where driver inattention is highly likely and, in turn, increases the probability of a collision occurring. Data from a naturalistic driving study conducted in Northern Virginia indicated that 78 percent of crashes and 65 percent of near-crashes involved some form of driver distraction in the preceding 3-second period (Klauer, Dingus, Neale, Sudweeks, \& Ramsey, 2006). Klauer et al. concluded that drivers engaging in a visually complex or manual-dexterity demanding task have approximately three times greater risk of a near-crash or crash.

As portable telephones, cell phones give the user the ability to communicate voice information wirelessly and are considered (for the purposes of this report) to be auditory communications devices. PDAs are hand-held computing devices for the management of contacts, tasks, and scheduling. Wireless PDAs may allow the user to browse the Internet and access email. Some PDAs can be expanded with additional features such as access to the Global Positioning System (GPS) for route navigation and turn-by-turn directions. Other PDAs include entertainment functions such as audio and video playback. However, the primary function of a PDA is visual information communications. Smart phones act as a combination of cell phones and PDAs, providing the user with a device combining both voice communications and wireless data communication/organization. Smart phones are both auditory and visual communication devices. However, due to their similar nature of distraction, for the purposes of this report PDAs will be considered as smart phone type devices.

These devices all pose the potential for distraction, if used while driving. However, they differ in the methods by which they cause distraction. This is largely because driving is a complex task requiring constant visual (Sivak, 1996) and auditory (Wiese and Lee, 2004) monitoring by the driver. At any point in time, at least one of the subsystems of working memory (either the phonological loop or visuo-spatial sketchpad; Baddeley, 2000) is likely to be occupied by the primary task of driving. The use of mobile electronic devices presents either visual or auditory information to which attention must be paid. The driver's cognitive resources are split between the competing demands of the driving task and the personal electronic device. This creates situations where drivers may miss critical driving cues and safety events, therefore increasing the risk of a collision or other serious safety-critical event. However, in order to study the effect of driver distraction adequately, definitions that are more suitable to measurement and research are needed.

Various researchers have proposed many definitions of driver distraction that attempt to account for the source of distraction. Regan, Young, and Lee (2009, p. 3) define driver distraction as "the diversion of attention away from activities critical for safe driving toward a competing activity." This definition is suitably broad (including both visual and auditory channel distracters) and allows for a wide range of distraction sources. Another practical definition is proposed by 
Ranney, Mazzae, Garrott, \& Goodman (2000, p. 1), who define driver distraction as "any activity diverting attention away from the [primary] task of driving.” They further separate driver distraction into four categories: visual distracters, auditory distracters, biomechanical distracters, and cognitive distracters. They illustrate how wide ranging this definition of distraction is by noting that acts such as tuning a radio or adjusting mirrors are potential sources of driver distraction. In addition, a single distracter within the Ranney et al. definition may belong to multiple categories; dialing a cell phone involves cognitive (remembering a telephone number), visual (scanning for the correct telephone button), and biomechanical (performing button presses) tasks. Considering both the source and the mechanism of distracters is especially useful as the number and variety of possible distraction sources increase (Wallace, 2003).

The following sections outline the effect of the use of mobile electronic devices on driver performance and transportation safety. Mobile electronic devices such as cell phones, PDAs, and smart phones have been found to have deleterious effects on driver performance when used during driving, especially in regards to their visual demand. The available literature on driver distraction was reviewed and summarized based on the effects of distraction on primary aspects of driver performance. Based on the literature, four areas of driver performance were identified: lateral control, longitudinal control, reaction time, and workload.

\subsubsection{Effects on Driver Performance}

\subsubsection{Lateral Control}

Driver control over the lateral, or lane, position of a vehicle is a commonly used measure of driver performance. This measure is the position of the vehicle in relation to the center of the vehicle's current and intended travel lane. The ability of the driver to maintain the vehicle on or near the center of the travel lane has traditionally been used as a marker of driving performance; however, various associated measures of lateral control (such as average lane position, variability/standard deviation in lane position, frequency of lane deviations, steering wheel angle, and reversal rate) have also been used (Regan, Lee, \& Young, 2008).

Research has demonstrated that cell phone use leads to significant increases in driver errors. A simulator study conducted by Abdel-Aty (2003) reported that drivers were much more likely to make errors, including lateral deviations, while using a cell phone to answer a phone call from the experimenter. Laberge, Scialfa, White, and Caird (2004) compared cell phone conversations with conversations between drivers and passengers in a driving simulator-based task and found that drivers were more likely to drive closer to the shoulder while distracted by any form of conversation. Likewise, instrumented vehicles studies have demonstrated that entering information into a cell phone leads to increases in the frequency and magnitude of lane deviations (Green, Hoekstra, \& Williams, 1993). Reed and Green (1999) examined this through a study of drivers' use of cell phones while operating vehicles. Drivers performing a dialing task concurrent with otherwise nominal driving had significantly more lateral vehicle movements and steering wheel input variations when compared to a non-distraction period of driving. Similarly, Shinar, Tractinsky, and Compton (2005) conducted a simulator study examining the effects of driver distraction (e.g., from cell phone use) on average lane position. Shinar et al. found that lane position stability significantly degraded with a cell phone distraction task. There was also a significant interaction between travel speed and lane position over time. With increased exposure, drivers traveled significantly closer to the shoulder, especially when following a lead 
vehicle. When examining the variability in lane position, there were significant effects for age of the driver (older drivers displayed significantly greater variance in lane positioning as compared to young or middle-aged drivers). Additionally, Shinar et al. measured steering variability through rate and frequency of steering wheel corrections. Their findings indicated that while steering variability significantly changed with distraction, there was no clear pattern depending on the type of distraction. This may be seen as evidence that distraction has a globally negative impact on steering variability.

Interestingly, laboratory findings have not been replicated in real-world driving measured through naturalistic data collection means. Sayer et al. (2007) measured 36 drivers in a naturalistic setting and found that steering variance and lateral lane position means were higher under secondary task conditions, however there were no significant differences between the secondary tasks (which included conversations, grooming, cell phone use, eating/drinking, and multiple secondary tasks). This suggests that the magnitude of real-world driver distraction effects may be less than those observed in laboratory settings, with the majority of the risk accompanying the visual and/or manual components of phone use.

\subsubsection{Longitudinal Control}

When drivers are engaged in a secondary task such as using cellular phones or PDA devices, fewer attentional resources are available to monitor and control vehicle speed. This, in turn, is reflected in greater variations and deviations from the pre-distraction speed as well as decreased headway (time to collision). Because of this, a number of researchers have used driver longitudinal control (or speed control) as a measure of the effect of driver distraction. Most hypotheses of distraction's effects on speed control have predicted lower average speeds with greater variability under distraction conditions. However, it is worth noting that in real-world situations drivers may adapt strategies such as lower speeds as a compensatory measure (Sayer, Devonshire, \& Flannagan, 2007).

Harms (1991) hypothesized that variations in mental workload due to the complexity of a driving scenario and secondary distraction tasks would be reflected in driving speed. In a simulator study, Harms found that when drivers experienced an increase in task loading, vehicle speed was reduced. Later research by Reed and Green (1999) compared driving while dialing a telephone to a nominal driving period in both simulator and instrumented vehicle modalities and noted that, in both simulator and real vehicle settings, the use of a telephone results in greater variability around mean speed and throttle position. Similar findings were reported from a simulator study conducted by Shinar et al. (2005), who noted that distractions from the driving task such as cell phones and other personal technologies make it more difficult for drivers to maintain a set speed. Shinar et al. found that distractions lead to increased variance around the driver's mean speed. In addition, they also noted a significant distraction/age interaction, with older drivers exhibiting a greater amount of variance around their mean speed as compared to younger drivers under distracted driving conditions.

However, some research has noted opposite driver distraction effects on speed control. Recarte and Nunes (2002) explored drivers' speed control under both restricted and unrestricted driving speeds in an instrumented vehicle driving task. These researchers found that distraction might actually lead to an increase in mean speed under some conditions, which contradicts the majority of previous research findings. They speculated that this increase was due to drivers attempting to 
maintain an optimal speed for the roadway, combined with attentional narrowing, which reduced secondary speed cues from the roadway environment. Although a logical explanation, it is interesting that other researchers have not noted similar findings or proposed similar operational mechanisms.

Sayer et al. (2007) observed 36 drivers in a naturalistic study of driving behavior. For most drivers in their sample, under distraction conditions (through secondary tasks, including cell phone use), speed variance was lower than in baseline conditions. Although Sayer et al. determined that throttle variance had increased under secondary task conditions, the resulting speed variance (considered the ultimate, practical, measure of control outcome) was actually lower. This suggests that drivers were ultimately exercising greater longitudinal control under distraction conditions, although they had to use more throttle inputs to achieve this. This contrast between naturalistic measurement and laboratory experiments should be taken into consideration when attempting to predict the real-world outcomes from distraction conditions. The effects seen in laboratory conditions are often not applicable to the real world.

\subsubsection{Reaction Time}

Driver distraction research has often used reaction time to roadway events as a performance measure and a secondary measure of safety. Although most of the driving task may be performed with only minor levels of conscious effort, safe driving is assumed to depend on the driver having the focused attention necessary to constantly monitor the forward roadway and detect hazardous situations. When the driver's attention is occupied by secondary (distracter) tasks, the ability to detect such hazards in a timely fashion is negatively impacted. This distraction effect is reflected in increased reaction times to events and hazards, as well as an increase in the occurrence of undetected hazards.

Hancock, Simmons, Hashemi, Howarth, and Ranney (1999) examined the effect of a visual distraction task on driver reaction time. This was performed as an instrumented vehicle test-track experiment, where drivers were required to react to the change in a traffic signal (green to red directly, an action which forced a driver response by eliminating the decision "dilemma zone" created by the amber light). These researchers found that drivers' brake reaction time to the red light increased significantly under distraction conditions; the undistracted average brake reaction time of 0.61 seconds rose to almost a full second in distraction conditions. Variability in braking responses also increased under distraction conditions. Drivers were required to brake more intensely following a foreshortened distance between the stop line and their vehicle; this situation was viewed as increasing the likelihood of a rear-end collision with a following vehicle. Hancock et al. concluded that driver distractions present an immediate hazard for the driver and passengers as well as for other roadway vehicles.

In a later study, Hancock, Lesch, and Simmons (2003) reported similar findings from a study of 42 drivers. Drivers in this study completed a phone task while driving an instrumented vehicle on a closed test track. Drivers who were using the cell phone while driving had significantly impaired reactions to roadway events. Specifically, drivers using cell phones had a 15 percent increase in non-responses to a stoplight as compared to drivers who were not using cell phones. Hancock, Lesch, and Simmons concluded that the use of in-vehicle technologies such as cell phones significantly degraded performance safety and were significant distracters from the primary task of driving the automobile. 
Similar non-response findings were noted by McKnight and McKnight (1993) in a study examining driver responses to videos of potential roadway hazards. Participants in this study observed a 25-minute video of 45 different highway traffic scenarios, requiring the participant to respond using simulated vehicle controls. Four distraction levels were examined and compared to the baseline of "no distraction": placing a phone call, carrying on a casual phone call (e.g., what the participant did for a living, hobbies, etc.), carrying on an intense phone call (e.g., requiring the participant to solve math and short-term memory problems), and tuning a radio. The findings indicated that within each distraction level, the potential for a non-response to the hazard increased as compared to a baseline comparison. Intense phone conversations had the greatest proportion of non-responses, similar to the decrements observed with the visually demanding task of tuning a radio. Placing calls and casual conversations demonstrated significantly lower levels of decrements.

Laberge et al. (2004) reported the findings of a driving simulator experiment comparing the distraction potential from conversations with passengers versus those carried out during a cell phone call. Their study compared driver behavior in three conditions: conversing on a cell phone, conversing with a fellow participant serving as a passenger, and driving alone. Laberge et al. found a significant difference in response times to a pedestrian incursion. Drivers who were engaged in a conversation, regardless of the modality, had significantly increased (i.e., degraded) reaction times to a pedestrian in the forward roadway. In addition to supporting the evidence of increased reaction time under distracted driving conditions, these results are interesting as they provide some contrary evidence to the common assumption that passengers modulate their conversational pace with respect to roadway conditions.

In a simulator-based task manipulating the control over in-vehicle messaging, Jamson, Westerman, Hockey, and Carsten (2004) found that while drivers were making adjustments in their headway (increasing their headway from a lead vehicle) during a distracting task, they were significantly less likely to anticipate the braking of a lead vehicle. This was reflected in the significant increases in braking reaction time. Likewise, Reed and Robbins (2008) examined the effect of using Short Message Service communications (text messages) while driving. Drivers attempting to complete a text message had a variety of deficits, including increased lane variability and reduced vehicle speed. Drivers also had greatly increased reaction times to roadway events. When examining the impact of reading a received message, similar findings were present, although at a lesser magnitude. Interestingly, participants were aware that their driving was impacted during these distraction tasks and reported attempts to drive with a larger safety margin. However, this was not reflected in the decrements observed in many of the performance measures, including reaction time.

Although measures of lateral control, longitudinal control, and reaction time typically are used in distraction research, there is some evidence that driver gap acceptance (the space between oncoming vehicles that a driver intends to turn across, say to make a left hand turn from a twolane road in North America) is affected. In a test track experiment, Cooper and Zheng (2002) examined the effect of an auditory processing distraction task on intersection gap acceptance judgments. Their results indicate that age, gap size, speed, and pavement condition all influenced the gap acceptance decision. However, when participants were asked to perform gap acceptance decisions while simultaneously performing an auditory processing task, participants no longer accounted for the pavement conditions (e.g., whether the road surface was wet or dry) in their 
decision-making process. Drivers were equally likely to accept a given gap in wet or dry conditions, even though the relative safety of the wet conditions was reduced.

As noted by Summala (2002), drivers may understand the relative risk of distracted driving and attempt to increase their headway during car following. This allows a longer reaction time to still fall within a period where a response will be effective. However, Summala also pointed out that driver determination of adequate headway can be ineffectual, and expectations of the roadway can be violated. Thus, drivers may not always be relied upon to compensate for distraction effects.

\subsubsection{Workload}

The introduction of new technologies in motor vehicles (such as cell phones and other attentiondemanding devices) presents questions related to their impact on driver workload. When the distraction task loading occurs through the auditory channel, as in the form of a cell phone call, the additional information (and, in some cases, the content of the information) has been found to influence performance.

An instrumented vehicle study by Harbluk, Noy, and Eizenman (2002) examined changes in drivers' visual scanning driving patterns under three levels of distraction: no distraction, an easy cognitive task (i.e., simple addition tasks), and a difficult cognitive task (i.e., difficult addition tasks). As predicted, drivers had significantly increased hard-braking events under distracted driving conditions. Interestingly, drivers made fewer saccades (i.e., abrupt, rapid, small eye movements), spent more time focusing on the central visual field, and spent less time scanning the right periphery while performing a distraction task. This collapse of normal visual scanning behavior was reflected in driver subjective mental workload ratings, which increased significantly (along with subjective ratings of distraction) in distracted driving conditions. This suggests that under increased task load situations, visual scanning collapses to a minimal level, increasing the risk that a driver will miss a critical event. These findings were supported by Schreiner, Blanco, and Hankey (2004), who found that drivers exhibited a decreased percentage of glance time toward the forward roadway and speedometer and increased response times to visual events (i.e., forward and peripheral areas) while manually dialing the cell phone as compared to the baseline driving condition.

Similar results were found in a large-scale naturalistic observation study performed by Klauer et al. (2006), who determined that the risk of a safety-critical event occurring during mobile device use was greatest during dialing. This was reflected in an odds ratio significantly greater than that of baseline driving. The odds ratio found that talking or listening to a hand-held device was not significantly different from baseline (i.e., non-eventful) driving. The greatest risk was found to occur during the visually demanding act of dialing. Although this study was conducted prior to the widespread introduction of hands-free phone units, it is likely that hands-free (as compared to hand-held) interactions would likely impart less demand on the driver. Further support for this is found in the Klauer et al. finding that simple secondary tasks did not significantly elevate risk, while moderate and complex secondary tasks did. Thus, the demand presented by the device appears to influence the safety of its use while driving.

Tijerina, Kiger, Rockwell, and Tornow (1995) examined the workload of commercial heavyvehicle drivers while using cell phones and text messaging devices in an instrumented heavy 
vehicle. Their results indicate that the use of a cell phone, particularly dialing, leads to an increase in driver workload. Some measures of driver performance also sensitive to workload variations (such as speed control) did not appear to covary with the use of cell phones and text messaging devices. However, lane control performance was found to degrade significantly while drivers were concurrently using a cell phone or text messaging device. Tijerina et al. concluded that the additional task demand imparted by in-vehicle devices could degrade the performance of over-learned vehicle control skills (such as lane keeping and speed maintenance), even in highly trained CMV drivers. This was seen as increasing both the workload and risk of collisions as well as decreasing driver safety.

Mixed evidence regarding the impact of device type (specifically, hand-held versus hands-free device use) has been found. An on-road study by Matthews, Legg, and Charlton (2003) examined three types of cell phones (i.e., hand-held, hands-free [speakerphone], and headset). These three phone configurations were examined in terms of their in-use impact on driver mental workload as participants drove a specified route. Results indicated significant differences in mental workload between the three types of phones. The headset configuration was associated with the lowest mental workload ratings, followed by the hand-held phone. The hands-free speakerphone was associated with the greatest workload ratings - the sound quality was not clear as background noise rendered the conversation unintelligible. These authors concluded that the use of headset-based phones while driving would lead to less interference with the cognitive demands of driving.

\subsection{SUMMARY}

Driver distraction has long been recognized as a threat to transportation safety. One naturalistic driving study of a sample of drivers in Northern Virginia found that 78 percent of the crashes and 65 percent of near-crashes were preceded by drivers looking away from the forward roadway just prior to the onset of the conflict. (Klauer et al., 2006). As industry estimates suggest that approximately 90 percent of Americans own and use cell phones (CTIA-The Wireless Association, 2009), and that at any moment during the day approximately 800,000 drivers are talking on a cell phone while driving (Glassbrenner \& Ye, 2007), driver distraction related to the use of cell phones becomes a serious concern. Initial analyses of naturalistic driving data indicate notable effects on commercial driving performance while performing visually intensive cell phone tasks (such as dialing; Olson, et al., 2009). However, by far, the most notable distraction found was text messaging. CMV drivers who are text messaging while operating their vehicles are approximately 23 times more likely to be involved in a safety-critical event as compared to non-text-messaging drivers (Olson et al.).

As mentioned before, driver distraction (and especially CMV driver distraction) is a rapidly evolving field. Thus, it is important to note that the majority of the literature collected in this effort was available prior to May 2009. As more recent examinations are published, as well as research that is able to quantify the actual risk associated with distraction in the real world, these findings should be reevaluated. Likewise, it is important to view the published research through the context of the method of data collection. Simulator studies have produced results that do not agree with the frequency or magnitude of distraction related events in the real world. Additionally, the applicability of findings related to automobile driving may not apply to CMV 
operations due to the fundamental differences of operating an automobile and operating a large articulated vehicle, as well as the different exposure associated with the typically higher annualized vehicle miles traveled logged by CMV operators as compared to automobile drivers.

Finally, it should be noted that the majority of the extant literature does not specifically examine individual tasks associated with cell phone use (dialing vs. conversation). More recent studies published have indicated significant differences between the risk of dialing a phone and simply conversing on the phone (Olson et al., 2009). Thus, drawing overarching conclusions from these studies may be problematic. However, the findings may help to determine what areas of cell phone use within truck and motorcoach operations should be examined further.

As the technology research and design communities gain increased understanding of the potential increases in risk presented by drivers using mobile communication technologies (such as cell phones and PDAs), attempts to mitigate the impact of such distractions have been undertaken. SAfety VEhicle(s) using adaptive Interface Technology (SAVE-IT), a study released in May 2008, investigated using adaptive warnings (e.g., lane departure warnings or forward collision avoidance technology) that would only sound a warning if the driver was not watching the forward roadway, and adaptive driver-vehicle interface technology that would control the function of mobile devices in potentially dangerous driving events. However, any attempt at designing driver assistance systems that mitigate the increased task demand posed by in-vehicle communications must consider both the visual and auditory channels (Vollrath \& Totzke, 2000).

Both visual and auditory distractions must be accounted for in order to ensure that distraction is effectively mitigated. A modern distraction and drowsiness detection system investigated by Kircher, Kircher, and Claezon (2009) has attempted to use eyes-off-roadway time as a metric-a marker of distraction risk as noted by Klauer et al. (2006) — and notify drivers of potential distracted driving through vibrations in the seat pan. Summala (2002) noted that drivers are occasionally able to perform some, albeit limited, distraction mitigation strategies on their own. However, Summala also explained that drivers' expectations are not always valid and that their choices are occasionally incorrect. Hence, there is an increased risk associated with cell phones and PDAs noted by the majority of the literature.

Some attempts to quantify and limit the distraction potential of new in-vehicle devices have been proposed. One example, the "15-Second Rule," depends on an in-vehicle task being executed while stationary within a 15-second-or-less period (SAE International, 2004; Green, 1999). However, this standard has not proven to be sensitive to driver distraction in experimental conditions (Tijerina et al., 2000). Ongoing attempts to develop practical and easily applicable guidelines for the measurement of distraction in motorcoach operations are needed. 


\section{CONCLUSIONS}

The results of the literature synthesis indicated that, although substantial literature examining the effects of driver distraction exists regarding wireless communication devices (such as cell phones), the literature primarily covers only the effects of distraction on non-commercial automobile driving. Little information is present regarding the effect of distraction on the professional truck driver and even less information is specifically related to the motorcoach driver. The findings in the current literature focus primarily on the associated increases in risk presented by the use of mobile phones while driving a vehicle. While some newer literature has examined the effects of devices (e.g., PDAs and GPS navigation systems that are primarily visually demanding), such research has not generally extended to devices specific to the CMV driver (e.g., dispatching devices). In the course of this literature review, the only reference made to distraction as related to operating a motorcoach was found in legislative items. The research community has not adequately examined distraction within motorcoach operations and the unique driver tasks associated with motorcoach operations. Thus, one key finding of the literature review is that further research is essential to understanding the relationship between distracted driving and the safe operation of a motorcoach.

Although operation of a motorcoach appears to be similar to the operation of a light vehicle, several important differences must be kept in mind when comparing the two, or drawing conclusions from research dealing with only one. In addition to being responsible for the safe operation of a motorcoach on public roads, the motorcoach operator is often responsible for such tasks as managing passengers; remaining on predetermined timetables; maintaining communications with a dispatching office, tour agency, and destination; as well as announcing the arrival at attractions. While some of these tasks are required of heavy truck drivers, enough differences are present for the operation of a motorcoach to be viewed as fundamentally different from that of a tractor-trailer. As mentioned earlier, the literature lacks results from empirical research regarding motorcoach operators and forces the research and design community, regulators and the transportation industry to rely on the extrapolation of findings from automotive and trucking research. However, similar distraction deficits could be expected to affect the safe operation of a motorcoach as they affect the safe operation of a heavy truck.

A naturalistic driving study with motorcoaches would provide detailed information about the actual technology usage and factors that lead to all forms of driver distraction. Motorcoaches could be instrumented with cameras and other sensors while motorcoach drivers make their normal, revenue-producing trips. The primary goal of such a study would be to investigate crashes, near-crashes, and crash-relevant conflicts from the motorcoach driver's perspective to help determine functional countermeasures. Identifying these functional countermeasures would assist in the development of effective technologies, enforcement strategies, training and education programs, and other specific countermeasures to reduce motorcoach crashes and their associated injuries and fatalities.

Overall, the literature identified in the process of this synthesis indicates consistent degradations in driver performance due to the effects of driver distraction. This degradation in driver performance leads to increased risk of critical events (such as pedestrian incursions and traffic signals) being missed by drivers and possibly to an increased overall risk of a crash or nearcrash. The greatest risk from cell phones/smart phones appears to occur during operational tasks 
that are primarily visual in nature. Actions such as entering information into a device or dialing a cell phone require significant visual attention focus that leads to greatly increased crash risk.

Some evidence exists that suggests that the risk associated with cell phones/smart phones may be reduced through design that considers driver workload. However, additional research is needed prior to determining the differential risk from devices. Furthermore, research specifically examining driver distraction in a motorcoach operation setting is needed.

This rapid evolution of distracted driving research necessitates further investigation of both the body of scientific literature and truck and motorcoach company practices and CMV driver opinions. 


\section{REFERENCES}

AAA Foundation for Traffic Safety. (2008). Cell phones and driving: Research update. Washington, DC: AAA Foundation for Traffic Safety. Retrieved April 23, 2010, from http://www.aaafoundation.org/pdf/CellPhonesandDrivingReport.pdf

Abdel-Aty, M. (2003). Investigating the relationship between cellular phone use and traffic safety. Institute of Transportation Engineers Journal, 73(10), 38-42.

ATA. (2007). American Trucking Trends, 2005-2006. Arlington, VA: Author.

Baddeley, A. D. (2000). The episodic buffer: A new component of working memory? Trends in Cognitive Science, 4, 417-423.

Barr, L. C., Yang, C. Y. D., Hanowski, R. J., \& Olson, R. (2005). Assessment of driver fatigue, distraction, and performance in a naturalistic setting. Transportation Research Record, 1937, 51-60.

CTIA-The Wireless Association. (2009). Wireless quick facts. Washington, DC: CTIA-The Wireless Association. Retrieved April 23, 2010, from http://www.ctia.org/media/industry_info/index.cfm/AID/10323

Cooper, P. J., \& Zheng, Y. (2002). Turning gap acceptance decision-making: The impact of driver distraction. Journal of Safety Research, 33(3), 321-335.

Dingus, T. A., McGehee, D., Hulse, M., Jans, S., \& Manakkal, N. (1995). Travtek evaluation task C3: Camera car study (Report No. FHWA-RD-94-076). McLean, VA: Federal Highway Administration Office of Safety and Traffic Operations.

Glassbrenner, D., \& Ye, T. J. (2007). Driver cell phone use in 2006: Overall results (Report No. DOT HS 810 90). Washington, DC: USDOT, NHTSA.

Goodman, M., Bents, F. D., Tijerina, L., Wierwille, W. W., Lerner, N., \& Benel, D. (1997). An investigation of the safety implications of wireless communications in vehicles (Report No. DOT HS 808-635). Washington, DC: National Highway Traffic Safety Administration.

Green, P., Hoekstra, E., \& Williams, M. (1993). Further on-the-road tests of driver interfaces: examination of a route guidance system and car phone (Report No. UMTRI-93-35). Ann Arbor: University of Michigan Transportation Research Institute.

Green, P. A. (1999). The 15-Second rule for driver information systems. (Vol. 9). Washington, D.C.: Intelligent Transportation Society of America.

Hahn, R.W., \& Dudley, P.M. (2002). The disconnect between law and policy analysis: A case study of drivers and cell phones (Report 02-07). Washington, DC: AEI-Brookings Joint Center for Regulatory Studies.

Hancock, P. A., Lesch, M., \& Simmons, L. (2003). The distraction effects of phone use during a crucial driving maneuver. Accident Analysis and Prevention, 35(4), 501-514.

Hancock, P. A., \& Scallen, S. F. (1999). The driving question. Transportation Human Factors, 1(1), 47-55. 
Hancock, P. A., Simmons, L., Hashemi, L., Howarth, H., \& Ranney, T. (1999). The effects of invehicle distraction on driver response during a crucial driving maneuver. Transportation Human Factors, 1(4), 295-309.

Hanowski, R. J., Perez, M. A., \& Dingus, T. A. (2001). Driver distraction in long-haul truck drivers. Transportation Research Part F, 8,441-458.

Harbluk, J. L., Noy, Y. I., \& Eizenman, M. (2002). The impact of cognitive distraction on driver visual behavior and vehicle control (Report No. TP 13889E). Ottawa: Transport Canada.

Harms, L. (Ed.). (1991). Experimental studies of variations in cognitive load and driving speed in traffic and driving simulation. Amsterdam: Elsevier.

Insurance Institute for Highway Safety. (2009). Cellphone laws. Retrieved May 2009 from http://www.iihs.org/laws/cellphonelaws.aspx.

Jamson, A. H., Westerman, S. J., Hockey, G. R. J., \& Carsten, O. M. J. (2004). Speech-based email and driver behavior: Effects of an in-vehicle message system interface. Human Factors, 46, 625-639.

Kircher, K., Kircher, A., \& Claezon, F. (2009). Distraction and drowsiness - a field study. (No. 638A). Linkoping, Sweden: VTI.

Klauer, S. G., Dingus, T. A., Neale, V. L., Sudweeks, J. D., \& Ramsey, D. J. (2006). The impact of driver inattention on near-crash/crash risk: An analysis using the 100-car naturalistic driving study data (Report No. DOT HS 810 594). Washington, D.C.: National Highway Traffic Safety Administration.

Laberge, J., Scialfa, C., White, C., \& Caird, J. (2004). Effects of passenger and cellular phone conversations on driver distraction. Transportation Research Record, 1899, 109-116.

Lissy, K.S, Cohen, J.T., Park, M.Y., Graham, J.D. (2000). Cellular phone use while driving: Risks and benefits (Technical Report). Boston: Harvard Center for Risk Analysis.

Matthews, R., Legg, S., \& Charlton, S. (2003). The effect of cell phone type on drivers’ subjective workload during concurrent driving and conversing. Accident Analysis and Prevention, 35, 451-457.

McKnight, A. J., \& McKnight, A. S. (1993). The effect of cellular phone use upon driver attention. Accident Analysis and Prevention, 25(3), 259-265.

Olson, R.L., Hanowski, R.J., Hickman, J.S., \& Bocanegra, J. (2009). Driver distraction in commercial vehicle operations (Report No. FMCSA-RRR-09-042). Washington, DC: Federal Motor Carrier Safety Administration.

Pennay, D. (2008). Community attitudes to road safety: 2008 survey report (Report No. INFRA08366). Canberra, Australia: Dept. of Infrastructure, Transport, Regional Development and Local Government.

Ranney, T. A., Mazzae, E., Garrott, R., \& Goodman, M. J. (2000). NHTSA driver distraction research: Past, present, and future. Washington, D.C.: National Highway Traffic Safety Administration.

Recarte, M. A., \& Nunes, L. (2002). Mental load and loss of control over speed in real driving. Towards a theory of attentional speed control. Transportation Research Part F, 5, 111-122. 
Redelmeier, D. A., \& Tibshirani, R. J. (1997). Association between cellular-telephone calls and motor vehicle crashes. New England Journal of Medicine, 336(7), 453-458.

Reed, M. P., \& Green, P. A. (1999). Comparison of driving performance on-road and in a lowcost simulator using a concurrent telephone dialing task. Ergonomics, 42(8), 1015-1037.

Reed, N., \& Robbins, R. (2008). The effect of text messaging on driver behavior: A simulator study (Report No. PPR 367): Transportation Research Laboratory.

Regan, M. A., Lee, J. D., \& Young, K. L. (Eds.). (2009). Driver distraction: Theory, effects, and mitigation. Boca Raton: CRC Press.

Royal, D. (2003). National survey of distracted and drowsy driving attitudes and behaviors: 2002. Volume I: Findings. (Report No. DOT HS 809 566). Washington, DC: National Highway Traffic Safety Administration.

SAE International. (2004). Navigation and Route Guidance Function Accessibility while Driving (Document no. J2364). Warrendale, PA: SAE International. Retrieved April 23, 2010, from http://www.sae.org/technical/standards/J2364_200408

Safety Canada. (2004, January). Too many distractions. Safety Canada, 48(1), 3-4.

Sayer, J., Devonshire, J., \& Flannagan, C. A. (2007, July 9-12). Naturalistic Driving Performance During Secondary Tasks. Paper presented at the Fourth International Driving Symposium on Human Factors in Driver Assessment, Training and Vehicle Design, Stevenson, WA.

Schreiner, C., Blanco, M., \& Hankey, J. M. (2004). Investigating the Effect of Performing Voice Recognition Tasks on the Detection of Forward and Peripheral Events. Proceedings of the Human Factors and Ergonomics Society's $48^{\text {th }}$ Annual Meeting. Santa Monica, CA: Human Factors and Ergonomics Society: Santa Monica, CA.

Shinar, D., Tractinsky, N., \& Compton, R. (2005). Effects of practice, age, and task demands, on interference from a phone task while driving. Accident Analysis and Prevention, 37(2), 315326.

Sivak, M. (1996). The information that drivers use: Is it indeed 90\% visual? Perception, 25(9), 1081-1089.

Smith, M., Witt, G., and Bakowski, D., (2008). A Final Report of Safety Vehicles using adaptive Interface Technology (Task 15) from http://www.volpe.dot.gov/hf/roadway/saveit/docs.html

Stutts, J., Feaganes, J., Reinfurt, D., Rodgman, E., Hamlett, C., Gish, K., et al. (2005). Driver’s exposure to distractions in their natural driving environment. Accident Analysis and Prevention, 37(6), 1093-1101.

Summala, H. (2002). Behavioural adaptation and drivers' task control. In R. Fuller \& J. Santos (Eds.), Human Factors for Highway Engineers (pp. 189-200). Amsterdam: Pergamon.

Tijerina, L. (2010, January). Cognitive versus visual distraction and real-world driving safety: Why different research methods may yield different results. Work presented at the SAE 2010 Government-Industry Meeting, Washington, DC. 
Tijerina, L., Kiger, S. M., Rockwell, T. H., \& Tornow, C. (1995). Workload assessment of in-cab text message system and cellular phone use by heavy vehicle drivers on the road. Proceedings of the Human Factors and Ergonomics Society, 39, 1117-1121.

Tijerina, L., Parmer, E., \& Goodman, M. J. (2000). Preliminary evaluation of the proposed SAE J2364 15-Second rule for accessibility of route navigation system functions while driving. Proceedings of the IEA 2000/HFES 2000 Congress, 3278-3281.

Treat, J. R., Tumbae, N. S., McDonald, S. T., Shinar, D., Hume, R. D., Mayer, R. E., et al. (1977). Tri-level study of the causes of traffic accidents: Final report (Report No. DOT-HS034-3-535). Washington, DC: National Highway Traffic Safety Administration.

Tsimhoni, O., Smith, D., \& Green, P. (2004). Address entry while driving: Speech recognition versus a touch-screen keyboard. Human Factors, 46(600-610).

USDOT. (2009). Distraction.gov: The official U.S. Government Web site for distracted driving. Retrieved February 18, 2010, from http://www.distraction.gov/.

Executive Order No. 13,513, 74 F.R. 51225, October 62009.

USDOT. (2010). U.S. Transportation Secretary Ray LaHood Announces Federal Ban on Texting for Commercial Truck Drivers. Retrieved February 18, 2010, from http://www.dot.gov/affairs/2010/dot1410.htm/

Vollrath, M., \& Totzke, I. (2000). In-vehicle communication and driving: An attempt to overcome their interference. Unpublished report. Retrieved 3 June 2009 from http://www.psychologie.uniwuerzburg.de/methoden/texte/2000_vollrath_totzke_In_vehicle_communication_and_drivin g.pdf.

Wallace, B. (2003). Driver distraction by advertising: Genuine risk or urban myth? Proceedings of the Institution of Civil Engineers: Municipal Engineer, 156(3), 185-190.

Wiese, E. E., \& Lee, J. D. (2004). Auditory alerts for in-vehicle information systems: The effects of temporal conflict and sound parameters on driver attitudes and performance. Ergonomics, 47, 965-986. 


\section{BIBLIOGRAPHY}

Agent, K.R., Pigman, J.G., \& Langley, R.E. (2002). 2001 Traffic safety issues opinion survey (Report No. KTC-02/SPR249-02-1F). Lexington: University of Kentucky, Kentucky Transportation Center.

Beede, K. E., \& Kass, S. J. (2006). Engrossed in conversation: The impact of cell phones on simulated driving performance. Accident Analysis and Prevention, 38(2), 415-421.

Bunn, T. L., Slavova, S., Struttmann, T. W., \& Browning, S. R. (2005). Sleepiness/fatigue and distraction/inattention as factors for fatal versus nonfatal commercial motor vehicle driver injuries. Accident Analysis and Prevention, 37(5), 862-869.

Consiglio, W., Driscoll, P., Witte, M., \& Berg, W. P. (2003). Effect of cellular telephone conversations and other potential interference on reaction time in a braking response. Accident Analysis and Prevention, 35(4), 321-335.

De Waard, D., Brookhuis, K. A., \& Hernandez-Gress, N. (2001). The feasibility of detecting phone-use related driver distraction. International Journal of Vehicle Design, 26(1), 85-95.

Fuse, T., Matsunaga, K., Shidoji, K., Matsuki, Y., \& Umezaki, K. (2001). The cause of traffic accidents when drivers use car phones and the functional requirements of car phones for safe driving. International Journal of Vehicle Design, 26(1), 48-56.

Goodman, M. J., Tijerina, L., Bents, F. D., \& Wierwille, W. W. (1999). Using cellular telephones in vehicles: Safe or unsafe? Transportation Human Factors, 1(1), 3-42.

Greenberg, J., Tijerina, L., Curry, R., Artz, B., Cathey, L., Kochhar, D., et al. (2003). Driver distraction: Evaluation with event detection paradigm. Transportation Research Record, 1843, 1-9.

Hashemi, L., Simmons, L. A., Howarth, H. D., \& Hancock, P. A. (1998). Effects of an in-vehicle distractor upon driver performance [Abstract]. Proceedings of the Human Factors and Ergonomics Society Annual Meeting, 42, 1626.

Horrey, W. J., Wickens, C. D., \& Consalus, K. P. (2006). Modeling drivers' visual attention allocation while interacting with in-vehicle technologies. Journal of Experimental Psychology: Applied, 12(2), 67-78.

Jerome, C. J., Ganey, H. C. N., Mouloua, M., \& Hancock, P. A. (2002). Driver workload response to in-vehicle operations. International Journal of Occupational Safety and Ergonomics, 8(4), 539-548.

Kantowitz, B. (1995). Simulator evaluation of heavy-vehicle driver workload. Proceedings of the Human Factors and Ergonomics Society Annual Meeting, 39, 1107-1111.

Kantowitz, B. H., Hanowski, R. J., \& Tijerina, L. (1996). Simulator evaluation of heavy-vehicle driver workload: II: Complex secondary tasks. Proceedings of the Human Factors and Ergonomics Society, 40, 877-881.

Kass, S. J., Cole, K. S., \& Stanny, C. J. (2007). Effects of distraction and experience on situation awareness and simulated driving. Transportation Research Part F: Traffic Psychology and Behaviour, 10(4), 321-329. 
Laberge-Nadeau, C., Maag, U. B., F., Lapierre, S. D., Desjardins, D., Messier, S., \& Saidi, A. (2003). Wireless telephones and the risk of road crashes. Accident Analysis and Prevention, 35(5), 649-660.

Llaneras, R. E., Singer, J. P., \& Bowers-Carnahan, R. (2005). Assessment of truck driver distraction problem and research needs (Report No. DOT HS 809 883). Washington, D.C.: National Highway Traffic Safety Administration.

McCartt, A.T., Hellinga, L.A., \& Bratiman, K.A. (2006). Cell phones and driving: Review of research. Traffic Injury Prevention, 7(2), 89-106.

McEvoy, S. P., Stevenson, M. R., \& Woodward, M. (2007). The prevalence of and factors associated with, serious crashes involving a distracting activity. Accident Analysis and Prevention, 39(3), 475-482.

Patten, C. J. D., Kircher, A., Ostlund, J., \& Nilsson, L. (2004). Using mobile telephones: Cognitive workload and attention resource allocation. Accident Analysis and Prevention, 36(3), 341-350.

Pettitt, M., Burnett, G., \& Stevens, A. (2005). Defining driver distraction. Paper presented at the World Congress on the Intelligent Transport Systems.

Rakauskas, M. E., Gugerty, L. J., \& Ward, N. J. (2004). Effects of naturalistic cell phone conversations on driving performance. Journal of Safety Research, 35(4), 453-464.

Schattler, K. L., Pellerito Jr., J., McAvoy, D., \& Datta, T. K. (2006). Assessing driver distraction from cell phone use: A simulator-based study. Transportation Research Record, 1980, 87-94.

Smiley, A. (2005, October). What is driver distraction? Paper presented at the International Conference on Distracted Driving. Toronto, Ontario.

Strayer, D. L., Drews, F. A., \& Johnston, W. A. (2003). Cell phone-induced failures of visual attention during simulated driving. Journal of Experimental Psychology: Applied, 9(1), 2332.

Stutts, J. C., \& Hunter, W. W. (2003). Driver inattention, driver distraction and traffic crashes. Institute of Transportation Engineers Journal, 73(7), 34-45.

Stutts, J. C., Reinfurt, D. W., Staplin, L., \& Rodgman, E. (2001). The role of driver distraction in traffic crashes [Technical Report]. Washington, D.C.: AAA Foundation for Traffic Safety.

Tseng, W. S., Nguyen, H., Liebowitz, J., \& Agresti, W. (2005). Distractions and motor vehicle accidents: Data mining application on Fatality Analysis Reporting System (FARS) data files. Industrial Management and Data Systems, 105(9), 1188-1205.

Uno, H., \& Hiramatsu, K. (2000). Effects of auditory distractions on driving behavior during lane change course negotiation: Estimation of spare mental capacity as an index of attention distraction. JSAE Review, 21(2), 219-224.

Wang, J. S., Knipling, R. R., \& Goodman, M. J. (1996). The role of driver inattention in crashes: New statistics from the 1995 Crashworthiness Data System. Proceedings of the Annual Meeting of the Association for the Advancement of Automotive Medicine, 40, 377-392. 